\title{
UJI AKTIVITAS ANTIINFLAMASI EKSTRAK ETANOL DAUN PISANG AMBON (Musa paradisiaca L.) TERHADAP TIKUS PUTIH (Rattus norvegicus L.) YANG DIINDUKSI KARAGENAN
}

\section{ANTI-INFLAMMATORY ACTIVITY TEST OF ETHANOLIC EXTRACT OF BANANA LEAF (Musa paradisiaca L.) ON CARRAGEENAN-INDUCED PAW EDEMA IN WHITE RATS (Rattus norvegicus L.)}

\author{
Sukmawati $^{1}$, Yuliet ${ }^{1}$, Ririen Hardani ${ }^{1}$ \\ ${ }^{1}$ Jurusan Farmasi, Fakultas MIPA, Universitas Tadulako, Palu, Indonesia.
}

Received 20 Agustus 2015, Accepted 25 September 2015

\begin{abstract}
A B S T R A K
Penelitian ini bertujuan untuk mengetahui aktivitas dan dosis efektif ekstrak sebagai anti-inflamasi. Ekstrak dibuat dengan metode maserasi menggunakan pelarut etanol $96 \%$. Uji aktivitas antiinflamasi yang dilakukan dibagi dalam 5 kelompok perlakuan. Setiap kelompok terdiri dari 5 ekor tikus putih. Kelompok pertama (kontrol negatif) diberikan 0,5\% suspensi Na-CMC; kelompok ke-dua (kontrol positif) diberikan natrium diklofenak $9 \mathrm{mg} / \mathrm{kgBB}$; sedangkan kelompok ke-3, ke-4, dan ke-5 secara berturut-turut diberikan ekstrak daun pisang sebesar 500, 750 dan $1000 \mathrm{mg} / \mathrm{kgBB}$. Masing-masing tikus kemudian diinduksi menggunakan karagenan $1 \%$ secara subplantar. Diameter radang diukur dengan menggunakan jangka sorong dan volume radang menggunakan pletismometer dilakukan selama 6 jam dengan interval waktu 60 menit. Data dianalisis secara statistik menggunakan ANOVA (analysis of variance). Hasil penelitian menunjukkan bahwa kontrol negatif memiliki perbedaan yang signifikan dengan kelompok perlakuan lainnyadimana tidak menunjukkan efek anti-inflamasi. Sebagai kesimpulan, ekstrak etanol daun pisang memiliki aktivitas antiinflamasi yang efektif pada dosis $750 \mathrm{mg} / \mathrm{KgBB}$.
\end{abstract}

Kata kunci : Ekstrak etanol, Musa paradisiaca L., Anti-inflamasi, Diameter Radangan

\section{A B S T R A C T}

This study aims to investigate and to determine the anti-inflammatory activity and its effective dose. The extract was prepared by maceration method using ethanol $96 \%$. Anti-inflammatory activity test was performed in five different groups. Each group consisted of 5 rats. The 1st group (negative control) was given $0.5 \%$ CMC-Na suspension; the 2nd group (positive control) was given diclofenac sodium $9 \mathrm{mg} / \mathrm{KgBW}$; the $3 \mathrm{rd}$, 4th, and 5th groups were successively given the banana leaf extract as much as 500, 750 and $1000 \mathrm{mg} / \mathrm{KgBW}$. Each rat was then induced by $1 \%$ carrageenan and tested using subplantar method. The inflamed paw diameter was measured using a calliper while the inflamed paw volume using pletysmometer. The measurements were done for 6 hours long with intervals of 60 minutes. The data was statistically analyzed using ANOVA (analysis of variance). The results showed that the negative control had a significant difference with the other treatment groups which did not show any anti-inflammatory effect. In conclusion, ethanolic extract of banana leaf has effective anti-inflammatory activity at a dose of $750 \mathrm{mg} / \mathrm{KgBW}$.

Keywords: Ethanolic Extract, Musa paradisiaca L., Anti-inflammation, Inflamed Paw diameter

*Corresponding author : Sukmawati Sukmawati.umha@yahoo.com (ph: +62-813-5526-3639) 


\section{PENDAHULUAN}

Inflamasi merupakan suatu respon protektif normal terhadap luka jaringan yang disebabkan oleh trauma fisik, zat kimia yang merusak, atau zat-zat mikrobiologik (Mycek, 2001). Respon inflamasi ditandai oleh kondisi berupa rubor (kemerahan), kalor (panas), dolor (nyeri), tumor (pembengkakan) dan gangguan fungsi (Corwin, 2008). Inflamasi dapat bersifat lokal dan sistemik, dapat juga terjadi secara akut atau kronis yang menimbulkan kelainan patologis. Pengobatan inflamasi mencakup dua aspek, yang pertama adalah meredakan nyeri yang seringkali menjadi gejala dan yang kedua adalah upaya penghentian proses kerusakan jaringan. Pengurangan peradangan atau respon inflamasi menggunakan obat golongan steroid dan antinflamasi non steroid (AINS) sebenarnya dapat meredakan reaksi inflamasi dengan baik tetapi penggunaan dalam jangka waktu lama dapat memberikan efek samping. Penggunaan obat golongan steroid secara sistemik sebagai antiinflamasi dalam waktu yang lama justru memberikan efek samping berupa penurunan sintesis glukokortikoid endogen, menurunkan respon imun tubuh terhadap infeksi, osteoporosis, moonface dan hipertensi. Penggunaan obat antiinflamasi non steroid (AINS) secara sistemik dalam jangka waktu yang lama juga dapat memberikan efek samping berupa gangguan saluran pencernaan seperti ulkus peptik, analgesik nephropathy, mengganggu fungsi platelet dan menghambat induksi kehamilan (Goodman, 2003).

Saat ini minat masyarakat terhadap pengobatan dengan obat alam semakin meningkat. Pemanfaatan tanaman baik sebagai obat maupun tujuan lain merupakan salah satu fenomena yang terjadi saat ini. Tanaman obat mengandung banyak komponen senyawa aktif dan memiliki berbagai efek farmakologis yang perlu dibuktikan kebenarannya secara ilmiah.

Salah satu tanaman obat yang dapat dimanfaatkan untuk pengobatan antiinflamasi adalah daun pisang ambon. Sebagian masyarakat Desa Bambalemo Ranomaisi, kecamatan Parigi, kabupaten Parigi Moutong telah memanfaatkan daun pisang ambon sebagai tanaman yang dapat menurunkan bengkak. Informasi ini diperoleh peneliti, berdasarkan hasil wawancara dengan key informan bahwa daun pisang ambon kering dapat dimanfaatkan sebagai alternatif pengobatan untuk menurunkan bengkak dengan cara mengambil daun pisang ambon kering yang sudah berubah warna menjadi kuning kecoklatan yang diambil langsung dari pohonnya kemudian direndam dengan menggunakan air hangat lalu dikompreskan pada bagian yang bengkak. Tetapi masih kurang bukti ilmiah bahwa daun pisang ambon ini dapat menurunkan bengkak atau memiliki aktivitas sebagai antiinflamasi.

Berdasarkan uraian diatas, maka peneliti ingin mengetahui aktivitas antiinflamasi ekstrak etanol daun pisang ambon (Musa paradisiaca L.) terhadap tikus putih jantan (Rattus norvegicus L.) yang diinduksi karagenan $1 \%$.

\section{METODE PENELITIAN \\ Desain Penelitian}

Penelitian ini merupakan penelitian eksperimental murni dimana dilakukan perlakuan terhadap subjek uji dan bersifat eksploratif, yaitu untuk mengetahui aktivitas ekstrak etanol daun pisang ambon sebagai antiinflamasi.

\section{Waktu dan Tempat Penelitian}

Penelitian ini dilaksanakan pada bulan Februari sampai April 2015, bertempat di Laboratorium Farmakognosi-Fitokimia dan Laboratorium Farmakologi-Toksikologi Program Studi Farmasi, FMIPA, Universitas Tadulako.

\section{Persiapan Bahan Uji}

Bahan yang digunakan dalam penelitian ini adalah daun pisang ambon (Musa paradisiaca L.) yang diperoleh dari Kabupaten Parigi Moutong, Kecamatan Parigi, Desa Bambalemo Ranomaisi. Determinasi tanaman dilakukan di Lembaga 
Ilmu Pengetahuan Indonesia (LIPI) Pusat Konservasi Tanaman - Kebun Raya Bogor. Daun tersebut dibersihkan dengan air bersih kemudian diangin-anginkan dan dihaluskan hingga diperoleh serbuk kering. Serbuk kering daun salam sebanyak $500 \mathrm{~g}$ dimaserasi dengan etanol $96 \%$ selama 3 hari, kemudian disaring. Ekstrak cair yang diperoleh diuapkan dengan alat rotavapor sampai diperoleh ekstrak kental di Laboratorium Farmakognosi-Fitokimia Program Studi Farmasi Fakultas MIPA Universitas Tadulako.

\section{Uji Penapisan Fitokimia (Harbone, 1987)}

Ekstrak daun pisang ambon yang telah didapatkan kemudian diuji kualitatif terhadap adanya senyawa flavonoid, fenolik, saponin, steroid, terpenoid, alkaloid, dan tanin di Laboratorium Farmakognosi-Fitokimia Program Studi Farmasi Fakultas MIPA Universitas Tadulako.

\section{Pengujian Aktivitas Antiinflamasi}

Pada hari pengujian, masing-masing hewan ditimbang dan diberi tanda pada kaki kirinya. Kemudian diukur volume dan diameter kaki kiri tikus dengan menggunakan Pletismometer dan jangka sorong. Data yang diperoleh dicatat sebagai volume dan diameter awal (Vo dan Do) yaitu volume kaki sebelum diberi obat dan diinduksi dengan larutan karagenan. Masing-masing tikus diberi suspensi bahan uji secara oral sesuai dengan kelompoknya. Satu jam kemudian kepada masing-masing kelompok perlakuan diinduksi secara subplantar dengan $0,1 \mathrm{ml}$ larutan karagenan $1 \%$, setelah 30 menit dilakukan pengukuran dengan pletismometer dan jangka sorong. Dicatat volume dan diameter kaki tikus (Vt dan Dt) sebagai volume dan diameter kaki setelah diberi obat dan diinduksi dengan larutan karagenan. Pengukuran dilakukan setiap 60 menit selama 360 menit.

\section{Analisis Data}

Data hasil penelitian diuji normalitasnya dengan uji Saphiro Wilk. Data dikatakan terdistribusi normal jika $\mathrm{p}>0,05$. Kemudian dilanjutkan dengan uji homogenitas (uji Levene), nilai $\mathrm{p}>0,05$ berarti data yang didapatkan homogen. kemudian dianalisis secara statistik menggunakan metode ANOVA (Analysis Of Variance) dengan tingkat kepercayaan $95 \%$. Dilanjutkan dengan uji Duncan untuk mengetahui kelompok perlakuan yang berbeda signifikan dibandingkan dengan yang lainnya.

\section{HASIL DAN PEMBAHASAN}

\section{Hasil}

Hasil rendemen yang diperoleh dari proses ekstraksi sebesar 1,63\%. Berdasarkan penapisan fitokimia yang telah dilakukan diperoleh hasil bahwa ekstrak daun salam positif mengandung senyawa flavonoid, fenolik, dan tanin, sedangkan negatif terhadap saponin, terpenoid, alkaloid, dan steroid. Senyawa-senyawa inilah yang berperan dalam memberikan khasiat dan efek biologis.

Proses inflamasi dapat diukur dari besarnya volume udem (menggunakan pletismometer) kaki tikus dan ketebalan udem (menggunakan jangka sorong). Pengukuran dilakukan sebelum induksi dengan karagenan $1 \%$ sampai 6 jam setelah perlakuan.

Tabel 1. Persen radang rata-rata telapak kaki tikus tiap waktu pengamatan menggunakan Pletismometer.

\begin{tabular}{cccccc}
\hline Waktu & \multicolumn{5}{c}{ Nilai rerata \pm SD persen radang (\%) } \\
\cline { 2 - 6 } Menit) & $\mathrm{K}$ & $\mathrm{ND}$ & EDP500 & EDP750 & EDP1000 \\
\hline 60 & $28,25 \pm 2,58$ & $11,00 \pm 2,12$ & $16,00 \pm 3,16$ & $15,50 \pm 4,97$ & $25,27 \pm 6,37$ \\
120 & $52,50 \pm 11,45$ & $24,75 \pm 5,35$ & $39,50 \pm 3,50$ & $8,50 \pm 2,29$ & $26,00 \pm 0,70$ \\
180 & $54,75 \pm 15,35$ & $28,75 \pm 6,83$ & $36,25 \pm 4,14$ & $14,50 \pm 2,29$ & $19,50 \pm 5,50$ \\
240 & $87,75 \pm 6,29$ & $35,00 \pm 3,08$ & $33,00 \pm 6,96$ & $10,25 \pm 2,48$ & $23,25 \pm 7,66$ \\
300 & $152,62 \pm 6,82$ & $18,50 \pm 1,65$ & $59,00 \pm 7,68$ & $7,75 \pm 3,49$ & $9,50 \pm 4,15$ \\
360 & $75,50 \pm 6,80$ & $21,50 \pm 6,50$ & $50,75 \pm 5,67$ & $3,25 \pm 1,29$ & $9,00 \pm 7,54$ \\
\hline
\end{tabular}

Keterangan :

$\mathrm{K}=$ Kontrol Negatif

ND $\quad$ Natrium Diklofenak

$\mathrm{EDP}=$ Ekstrak Daun Pisang 
Tabel 3. Jumlah persen radang selama 6

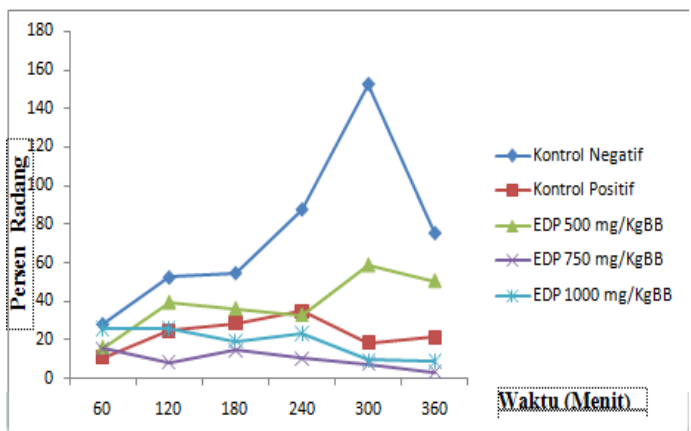

Gambar 1. Grafik persen radang rata-rata telapak kaki tikus tiap waktu pengamatan menggunakan Pletismometer

Tabel 2. Persen radang rata-rata telapak kaki tikus tiap waktu pengamatan menggunakan Jangka sorong.

\begin{tabular}{cccccc} 
Waktu & \multicolumn{5}{c}{ Nilai rerata \pm SD persen radang (\%) } \\
\cline { 2 - 6 } (Menit) & $\mathrm{K}$ & $\mathrm{ND}$ & $\mathrm{EDP} 500$ & EDP750 & EDP1000 \\
\hline 60 & $36,75 \pm 11,18$ & $35,00 \pm 2,73$ & $61,75 \pm 5,80$ & $41,75 \pm 3,34$ & $51,25 \pm 0,82$ \\
120 & $61,75 \pm 18,91$ & $33,75 \pm 8,52$ & $49,75 \pm 14,41$ & $34,75 \pm 10,96$ & $45,00 \pm 17,44$ \\
180 & $95,25 \pm 10,18$ & $24,25 \pm 5,53$ & $93,50 \pm 19,13$ & $49,00 \pm 3,80$ & $36,5 \pm 13,00$ \\
240 & $102,25 \pm 22,54$ & $21,50 \pm 4,55$ & $76,00 \pm 18,64$ & $48,00 \pm 8,12$ & $35,25 \pm 7,08$ \\
300 & $101,25 \pm 17,87$ & $7,50 \pm 0,86$ & $70,25 \pm 9,98$ & $39,00 \pm 8,27$ & $33,62 \pm 16,88$ \\
360 & $96,50 \pm 36,01$ & $5,00 \pm 2,12$ & $70,25 \pm 13,66$ & $27,00 \pm 6,51$ & $32,75 \pm 10,73$ \\
\hline
\end{tabular}

Keterangan :

$\mathrm{K}=$ Kontrol Negatif

ND $\quad$ Natrium Diklofenak

$\mathrm{EDP}=$ Ekstrak Daun Pisang

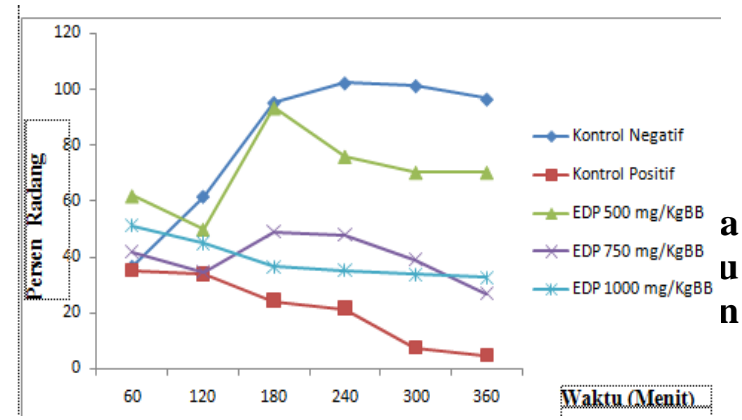

Hasil persentase radang yang diperoleh selama waktu pengamatan (6 jam), dihitung rata-ratanya kemudian dianalisis secara statistik One Way Anova dengan taraf kepercayaan $95 \%$. jam

\begin{tabular}{ccc}
\multicolumn{2}{c}{ jam } & \\
\hline Kelompok Perlakuan & \multicolumn{2}{c}{ Persen radang selama 6 jam } \\
\cline { 2 - 3 } & Pletismometer & Jangka sorong \\
\hline Kontrol Negatif & $75,22 \pm 41,27^{\mathrm{d}}$ & $82,29 \pm 33,19^{\mathrm{d}}$ \\
\hline Kontrol Positif & $23,25 \pm 9,14^{\mathrm{b}}$ & $21,16 \pm 12,81^{\mathrm{a}}$ \\
\hline EDP $500 \mathrm{mg} / \mathrm{KgBB}$ & $39,08 \pm 14,97^{\mathrm{c}}$ & $70,25 \pm 20,03^{\mathrm{c}}$ \\
\hline EDP $750 \mathrm{mg} / \mathrm{KgBB}$ & $9,95 \pm 5,25^{\mathrm{a}}$ & $39,91 \pm 10,78^{\mathrm{b}}$ \\
\hline EDP $1000 \mathrm{mg} / \mathrm{KgBB}$ & $18,83 \pm 9,39^{\mathrm{ab}}$ & $39,06 \pm 14,44^{\mathrm{b}}$ \\
\hline
\end{tabular}

Keterangan :

- Abjad yang sama menunjukkan perbedaan yang tidak bermakna.

- Abjad yang berbeda menunjukkan perbedaan yang bermakna.

\section{Pembahasan}

Karagenan merupakan suatu mukopolisakarida yang diperoleh dari rumput laut merah Irlandia (Chondrus crispus). Karagenan berperan dalam pembentukan udem dalam model inflamasi akut (Singh, 2008). Karagenan merupakan suatu zat asing (antigen) yang bila masuk ke dalam tubuh akan merangsang pelepasan mediator radang seperti histamin sehingga menimbulkan radang akibat antibodi tubuh bereaksi terhadap antigen tersebut untuk melawan pengaruhnya (Necas, 2013).

Aktivitas antiinflamasi suatu bahan obat adalah kemampuan obat dalam mengurangi atau menekan derajat udem yang dihasilkan oleh induksi hewan uji. Pengujian efek antiinflamasi dilakukan dengan menggunakan alat Pletismometer dan jangka sorong. Pletismometer memiliki prinsip pengukuran berdasarkan hukum Archimedes, yang menyatakan bahwa apabila benda dimasukkan ke dalam zat cair, maka akan menimbulkan gaya atau tekanan ke atas. Sedangkan penggunaan jangka sorong dengan tujuan untuk untuk mengukur diameter atau ketebalan radang pada kaki tikus. Metode pengukuran jangka sorong ini merupakan salah satu metode yang sering digunakan dalam uji antiinflamasi, relatif sederhana, baik dari instrumen yang dibutuhkan, proses perlakuan, pengamatan, pengukuran sampai dengan pengolahan data. 
Selang waktu pemberian semua perlakuan adalah 60 menit sebelum diberikan induksi suspensi karagenan dengan tujuan selang waktu 60 menit telah dapat menimbulkan efek secara maksimal untuk menurunkan udem. Pembentukkan radang oleh karagenan menghasilkan peradangan akut, dan tidak menyebabkan kerusakan jaringan, meskipun radang dapat bertahan selama 360 menit dan berangsur-angsur berkurang selama satu hari. Karagenan sebagai penyebab radang dapat dipengahuhi oleh obat antiradang. Responnya terhadap obat antiinflamasi lebih peka dibandingkan dengan antiiritan lainnya (Juheini, 1990). Ada tiga fase pembentukan udem yang diinduksi oleh karagenan. Fase pertama adalah pelepasan histamin dan serotonin yang berlangsung hingga 90 menit. Fase kedua adalah pelepasan bradikinin yang terjadi pada 1,5 hingga 2,5 jam setelah induksi. Pada fase ketiga, terjadi pelepasan prostaglandin pada 3 jam setelah induksi. Kemudian udem berkembang cepat dan bertahan pada volume maksimal sekitar 5 jam setelah induksi (Morris, 2003).

Pada Gambar 1 dan Gambar 2 dapat dilihat bahwa kontrol negatif tidak memiliki efek terhadap penghambatan radang akibat induksi karagenan karena tidak terjadi penurunan udem yang signifikan sampai pada menit ke 360. Tabel 3. menunjukkan bahwa persen radang terbesar terdapat pada kelompok kontrol negatif yaitu $75,22 \pm 41,27 \%$ (metode pletismometer) dan 82,29 $\pm 33,19 \%$ (metode jangka sorong). Persen radang pada semua kelompok uji mengalami penurunan secara bertahap sedangkan pada kelompok kontrol negatif proses radang masih berlangsung sampai jam ke-6 yang ditandai oleh persen radang yang masih terjadi sekitar $75,50 \pm 6,80 \%$ (metode pletismometer) dan $96,50 \pm 36,01 \%$ (metode jangka sorong) (Tabel 1 dan 2). Berdasarkan hasil perhitungan diperoleh bahwa kelompok EDP 500 $\mathrm{mg} / \mathrm{KgBB}$; EDP $750 \mathrm{mg} / \mathrm{KgBB}$ dan EDP $1000 \mathrm{mg} / \mathrm{KgBB}$ telah mempunyai daya antiinflamasi dengan persen radang berturut- turut sebesar 39,08 $\pm 14,97 \%$ (metode pletismometer) dan $70,25 \pm 20,03 \%$ (metode jangka sorong); 9,95 $\pm 5,25 \%$ (metode pletismometer) dan 39,91 $\pm 10,78 \%$ (metode jangka sorong); 18,83 $\pm 9,39 \%$ (metode pletismometer) dan $39,06 \pm 14,44 \%$ (metode jangka sorong) (Tabel 4.4). Efek antiinflamasi yang paling besar terdapat pada kelompok EDP $750 \mathrm{mg} / \mathrm{KgBB}$ dan EDP 1000 $\mathrm{mg} / \mathrm{KgBB}$. Efek antiinflamasi ditunjukkan oleh persen radang yang paling kecil selama pengamatan 6 jam. Berdasarkan hasil analisis One Way Anova yang dilanjutkan dengan uji lanjut Duncan menunjukkan bahwa kelompok EDP $500 \mathrm{mg} / \mathrm{KgBB}$ mempunyai efek antiinflamasi yang lebih rendah dan berbeda signifikan dibandingkan kelompok EDP 750 $\mathrm{mg} / \mathrm{KgBB}$ dan EDP $1000 \mathrm{mg} / \mathrm{KgBB}$. Hal ini diduga karena kurangnya konsentrasi atau jumlah ekstrak yang dapat berikatan dengan reseptor sehingga belum memberikan efek antiinflamasi yang berarti. Sedangkan pada kelompok EDP 750 mg/KgBB dan EDP 1000 $\mathrm{mg} / \mathrm{Kg}$ BB mempunyai efek antiinflamasi yang berbeda tidak signifikan. Hal ini menunjukkan bahwa ekstrak daun pisang dengan dosis $750 \mathrm{mg} / \mathrm{KgBB}$ merupakan konsentrasi yang efektif untuk berikatan dengan reseptor. Menurut Katzung (2002), intensitas efek obat berbanding lurus dengan reseptor yang diduduki atau yang diikatnya. Intensitas efek mencapai maksimal bila seluruh reseptor diduduki oleh obat. Oleh karena itu peningkatan dosis tidak memberikan peningkatan terhadap efek antiinflamasi.

Kelompok EDP $750 \mathrm{mg} / \mathrm{KgBB}$ dan EDP $1000 \mathrm{mg} / \mathrm{KgBB}$ memberikan efek antiinflamasi yang berbeda signifikan dibandingkan dengan kelompok kontrol positif Na.diklofenak pada metode pletismometer. Hal ini menunjukkan efek antiinflamasi ekstrak daun pisang dosis 750 $\mathrm{mg} / \mathrm{KgBB}$ dan $1000 \mathrm{mg} / \mathrm{KgBB}$ lebih baik dibandingkan Na.diklofenak. Namun pada metode jangka sorong hasil yang diperoleh sedikit berbeda dimana kontrol positif Na.diklofenak mempunyai efek antiinflamasi 
yang lebih baik dibandingkan kelompok uji ekstrak daun pisang. Hal ini diduga karena terdapatnya variasi biologis dan respon dosis yang berbeda pada masing-masing subyek (hewan uji) terhadap perlakuan yang sama. Selain itu, pengukuran yang kurang teliti terhadap volume udem dan diameter udem yang terjadi sehingga mempengaruhi hasil yang diperoleh.

Adanya efek antiinflamasi diduga karena aktivitas metabolit sekunder yang terdapat dalam ekstrak daun pisang ambon yaitu flavonoid, fenolik dan tannin. Hal ini didukung dengan hasil uji penapisan fitokimia yang menunjukkan adanya golongan senyawa tersebut. Flavonoid dalam tubuh bertindak menghambat enzim lipooksigenase yang berperan dalam biosintesis leukotrien (Robinson, 1995). Selain menghambat metabolisme asam arakidonat sehingga produksi prostaglandin dapat berkurang. Flavonoid juga menghambat sekresi enzim lisosom yang merupakan mediator inflamasi. Penghambatan mediator inflamasi ini dapat menghambat proliferasi dari proses radang (Robinson, 1995).

Selain flavonoid senyawa bioaktif lain yang berpotensi sebagai antiinflamasi yaitu tanin. Tanin mempunyai aktivitas antioksidan. Antioksidan berperan sebagai antiinflamasi dengan berbagai cara yaitu (1) menghambat produksi oksidan $\left(\mathrm{O}_{2}\right)$ oleh neutrofil, monosit dan makrofag. Penghambatan produksi oksidan $\mathrm{O}_{2}$ akan mengurangi pembentukkan $\mathrm{H}_{2} \mathrm{O}_{2}$ yang mengakibatkan produksi asam hipoklorid (HOCl) dan $\mathrm{OH}$ ikut terhambat. (2) menghambat langsung oksidan reaktif seperti radikal hidroksi $(\mathrm{OH})$ dan asam hipoklorid (Robinson, 1995).

Kesimpulan yang diperoleh dari penelitian ini bahwa Ekstrak etanol daun pisang ambon (Musa paradisiaca L.) memiliki aktivitas sebagai antiinflamasi terhadap tikus putih yang diinduksi karagenan. Dosis ekstrak etanol daun pisang ambon (Musa paradisiaca L.) yang dapat digunakan untuk memberikan efek antiinflamasi adalah EDP $750 \mathrm{mg} / \mathrm{KgBB}$.
Oleh karena itu perlu Perlu dilakukan penelitian lebih lanjut untuk mengetahui mekanisme kerja dan kandungan spesifik zat aktif yang berperan dalam antiinflamasi. Serta perlu dilakukan penelitian lebih lanjut mengenai metode peradangan lainnya seperti kasus OA (Osteoarthritis), luka bakar, atau penyebab autoimun lainnya.

\section{DAFTAR PUSTAKA}

Corwin, Elizabeth J. (2008). Handbook of pathophysiology 3th edition. Philadelphia. Lippincort Williams \& Wilkins.

Goodman, Gilman's. (2003). Dasar Farmakologi Terapi Edisi 10, Volume 2. Penebit Buku Kedokteran EGC. Jakarta.

Harborne, J.B. (1987). Metode Fitokimia Edisi II. Penerbit ITB. Bandung.

Juheini, F. W., Mariana. Y., \& Rusmawan. I. (1990). Efek Antiinflamasi Jahe (Zingiber officinale. Rosc) Terhadap Radang Buatan Pada Tikus putih. Majalah Farmakologi dan Terapi Indonesia. Jakarta.

Katzung B. G. (2002). Farmakologi Dasar dan Klinik Edisi 8. Salemba Medika. Jakarta.

Morris, Crhristoper J. (2003). CarrageenanInduced Paw Edema in the Rat and Mouse, In P.G. Winyard and D.A. Willoughby (Ed). Method in Molecular Biology. Vol. 225 : Inflammation Protocols. Totowa. NJ :Humana Press Inc.

Mycek, M. J. (2001). Farmakologi Ulasan Bergambar Edisi 2. Widya Medika, Jakarta.

Necas, J., Bartosikova, L. (2013). Carrageenan: a review, Faculty of Medicine and Dentistry. Palacky University. Olomouc. Czech Republic : Veterinarni Medicina. 58 (4): 187-205. 
Sukmawati et al./Galenika Journal of Pharmacy

Robinson, T. (1995). Kandungan Organik Tumbuhan Tingkat Tinggi. Penerbit ITB. Bandung.
Singh, Amritpal, Maholtra, S., \& Subban, R. (2008). Antiinflamatory and Analgesic Agents From Indian Medicinal Plants. International Journal of Integrative Biology. 